Article

\title{
Gender and Globalization of Academic Labor Markets: Research and Teaching Staff at Nordic Universities
}

\author{
Maria Pietilä ${ }^{1, *}$, Ida Drange ${ }^{2}$, Charlotte Silander ${ }^{3}$ and Agnete Vab $\varnothing^{4}$ \\ ${ }^{1}$ Human Resources Services, University of Eastern Finland, Finland; E-Mail: maria.pietila@uef.fi \\ 2 Work Research Institute, Oslo Metropolitan University, Norway; E-Mail: ida.drange@oslomet.no \\ ${ }^{3}$ Faculty of Social Sciences, Linnaeus University, Sweden; E-Mail: charlotte.silander@Inu.se \\ ${ }^{4}$ Faculty of Social Sciences, Oslo Metropolitan University, Norway; E-Mail: agnete.vabo@oslomet.no \\ * Corresponding author
}

Submitted: 1 February 2021 | Accepted: 9 June 2021 | Published: 21 July 2021

\begin{abstract}
In this article, we investigate how the globalized academic labor market has changed the composition of teaching and research staff at Swedish, Norwegian, and Finnish universities. We use national statistical data on the gender and countryorigin of universities' teaching and research staff between 2012 and 2018 to study how the globalized academic labor market has influenced the proportion of women across career stages, with a special focus on STEM fields. We pay special attention to how gender and country-origin are interrelated in universities' academic career hierarchies. The findings show that the proportion of foreign-born teaching and research staff rose substantially at the lower career level (grade $\mathrm{C}$ positions) in the 2010s. The increase was more modest among the most prestigious grade A positions, such as professorships. The findings show significant national differences in how gender and country-origin of staff intersect in Nordic universities. The study contributes to research on the gendered patterns of global academic labor markets and social stratification in Nordic universities.
\end{abstract}

\section{Keywords}

academic labor markets; country-origin; gender; global labor markets; intersectionality; Nordic universities; social stratification; universities

Issue

This article is part of the issue "Inclusive Universities in a Globalized World" edited by Liudvika Leišytè (TU Dortmund, Germany), Rosemary Deem (Royal Holloway, UK) and Charikleia Tzanakou (Oxford Brookes University, UK).

(C) 2021 by the authors; licensee Cogitatio (Lisbon, Portugal). This article is licensed under a Creative Commons Attribution 4.0 International License (CC BY).

\section{Introduction}

Gender equality has long been one of the key objectives in European research policies. However, gender balance has not been achieved in the most prestigious teaching and research (TR) positions in universities. There are far fewer women than men in top TR positions and as leaders of international research projects (European Commission, 2019). At the same time, recruitment patterns and career trajectories within the academic profession are undergoing significant changes due to an increasingly globalized labor market and international recruitment, although with variation by country and scientific field (Ackers, 2008).

We do not know how these changes will affect the gender composition of TR staff. One possible outcome is that patterns of gender inequality will be reproduced within global landscapes, as previous research indicates that women are less likely than men to take part in international research cooperation and mobility (Jöns, 2011; Metcalfe \& Woodhams, 2012; Vabø et al., 2014). Another possible outcome is that the global labor market will challenge established recruitment practices along the gender dimension. Based on data from the United States, Zippel 
(2017) argues that globalization can provide new opportunities for women to move to other national and institutional contexts and be liberated from exclusive organizational structures in their home environment. Thus, an empirical question remains as to how global recruitment of TR staff affects the gender composition of Nordic universities. The key argument in this article is that the consequences of a more globalized academic labor market for staff composition, with regard to gender and origin, will be context dependent and vary by country, career level, and scientific field.

Despite the increased globalization of the academic labor market (Enders \& Musselin, 2008) and policy efforts toward internationalization in higher education (Haapakoski \& Pashby, 2017; Huang et al., 2014), there is a lack of research on the gendered nature of the international recruitment of academics in different national contexts. Research on international academic recruitment has primarily been concerned with geographical mobility patterns (Ackers \& Gill, 2008; van der Wende, 2015) and the social stratification of universities' TR staff according to the origin of staff (Bauder, 2015; Khattab \& Fenton, 2016; Smetherham et al., 2010). Prior research conducted in the United Kingdom (UK) shows that foreignborn TR staff dominate in the lower career positions in universities (Khattab \& Fenton, 2016). It is important to research the outcomes of the globalized academic labor markets in different national contexts. Thus, this study focuses on these outcomes in the context of three Nordic countries: Sweden, Norway, and Finland. The composition of TR staff is addressed at two career stages through an intersectional lens. This allows us to visualize social stratification of Swedish, Norwegian and Finnish universities with respect to the origin and gender of staff at different grade levels, and the opportunities available for different social groups for upward career mobility.

In a European comparative report (Lipinsky, 2013), Sweden, Norway and Finland were identified as forerunners in the formulation of gender equality policies and in the implementation of measures to improve gender balance in research. On the aggregated level, gender balance has been achieved among PhD graduates (since 2005 in Finland, 2009 in Sweden, and 2012 in Norway; see Norbal database, 2021), albeit with significant differences between fields of science. However, the proportion of women in top positions in research still lags behind men.

To our knowledge, prior research has not used fullscale population data to study in a comparative setting how the global academic labor market is related to the proportion of women in general, or in different scientific fields. This shortage is partly related to the lack of comparable and reliable data (ETER Project, 2019; Teichler, 2015). The Nordic countries offer comparable, full-scale statistical data on the teaching and research personnel of their universities. Hence, our article covers this research gap and presents a comparative study that investigates how gender and country-origin intersect in the composi- tion of TR staff in three Nordic countries. We pose the following research questions: How has the globalization of the academic labor markets influenced the proportion of women at Swedish, Norwegian and Finnish universities in general, and in STEM fields (science, technology, engineering, mathematics) in particular? Are there discernible differences across grade levels? The study design allows us to make comparisons across countries, career phases and fields of science, as well as over time (2012-2018).

Gender and country-origin, and their intersection, are important dimensions when studying social stratification among university staff. Whereas previous research on global academic labor markets has largely neglected the intersectional perspective (Crenshaw, 1989), we apply this perspective to draw attention to how gender and country-origin are interrelated in academic careers in the Nordic countries. This approach should affect how we study and measure recruitment and promotion patterns in universities. The analysis concentrates on two critical career stages for university staff: grade $\mathrm{C}$ and grade $A$. Grade $C$ refers to career development positions (e.g., postdocs), whereas grade A refers to top career positions (e.g., professorships). The co-investigation of these stages provides insights into the inclusion of women and foreign-born TR staff in higher and lower status positions in universities, and thus forms a basis for further hypotheses on the intersectional nature of global university careers.

\section{Previous Research on Global Academic Labor Markets}

Supranational organizations, such as the European Union and the Organisation for Economic Co-operation and Development (OECD), and individual governments encourage geographical academic mobility. In the European Union, collaboration across national borders and international recruitment of researchers form a core part of the strategy toward a European research area (Gornitzka \& Langfeldt, 2009). These strategies can support international recruitment in specific segments of the academic labor market. For instance, the Marie Curie program promotes mobility to fixed-term research positions (Bauder, 2015; Khattab \& Fenton, 2016).

Global academic mobility has different push-andpull-factors (van der Wende, 2015), and the impact of these factors furthermore differs across institutions, fields and positions. In general, the mobility of TR staff is pursued because it is expected to improve the quality of higher education and research (Horta et al., 2010; Smetherham et al., 2010; Vabø \& Wiers-Jenssen, 2014). At the national level, international mobility is expected to increase knowledge production and place the country in a better position among competitive economies (Jonkers \& Tijssen, 2008). At the institutional level, mobility can support long-term collaboration and the production of new knowledge (Ackers \& Gill, 2008; Fontes 
et al., 2013). At the individual level, mobility is increasingly a required element in academic careers, especially for those who aspire to become part of the global academic elite (Khattab \& Fenton, 2016). Highly reputed universities display higher shares of academic staff from abroad (Khattab \& Fenton, 2016; Smetherham et al., 2010; Swedish Higher Education Authority, 2020). This indicates that the prestige and status of universities are important pull factors for researchers. However, Lepori et al. (2015) stated that the ability to attract researchers is explained mainly by country factors. This aligns with Khattab and Fenton's (2016) observation that different countries send and receive academic labor and that globalization is more pronounced in English-speaking countries.

Demographic change in universities, especially at the grade $\mathrm{C}$ level, can reflect a more international orientation in research, fierce competition for positions and a more egalitarian labor market (Khattab \& Fenton, 2016). However, it can also reflect a dualization of labor (Bauder, 2015; Musselin, 2004). The restructuring of the academic labor market with more external research funding, lower job security and lower wages implies that universities depend more on global labor to fill fixedterm, research-only positions (Bauder, 2015; Khattab \& Fenton, 2016; Smetherham et al., 2010). According to Khattab and Fenton (2016), in the UK, grade C positions are not attractive to native academics, who would rather opt for positions that provide better career opportunities. Hence, the overrepresentation of foreign-born academics in grade $\mathrm{C}$ in the UK implies their overrepresentation in the secondary academic labor market with few opportunities for career progression.

Research on global universities reveals some clear trends (Ackers \& Gill, 2005; Khattab \& Fenton, 2016; Smetherham et al., 2010). First, the presence of foreign-born academics increases over time. Second, the inflow of foreign-born academics is higher in subject fields associated with engineering and technology, compared with social sciences and humanities. Third, a division of labor crystallizes between nationals and foreign-born academics, as the foreign-born group dominates among fixed-term and research-only positions. Fourth, the more research-intensive and high-prestige universities have more foreign-born staff compared with teaching-intensive, new universities. However, the research does not provide evidence on where the global labor comes from, but some evidence corroborates that the elite institutions recruit more staff from the United States and not from the Global East and South (Khattab \& Fenton, 2016). In the Norwegian context, Askvik and Drange (2019) demonstrate that academics with majority origin and those who come from Europe and other Western countries display equal distribution across employment categories, whereas staff from the Global East and South are overrepresented in research and postdoc positions and underrepresented in grade $A$ and teaching positions.
The stratification of the academic labor market displays a hierarchy in which white, middle-class men keep the most prestigious positions. Nowadays, the share of native men in UK academia is declining, and they are being replaced with women and non-UK academics in the lower ranked positions, part-time and fixed-term employment (Khattab \& Fenton, 2016). The gender distribution is equal across non-UK and UK university staff, but non-UK staff are more prevalent in the younger age groups. This indicates that the global labor market first changed university demographics from below (Smetherham et al., 2010). Whereas for many individual academics, mobility can be a strategic choice, for some groups, the opportunities for mobility are highly restricted. Morley et al. (2018) emphasize that the opportunities for mobility are not equal among social groups but depend on the academics' gender, ethnicity, age, socioeconomic status and discipline.

\subsection{Women in the Global Academic Labor Markets}

Previous research indicates that women are less likely than men to participate in international collaboration and mobility (Ackers, 2008; Ackers \& Gill, 2005; Jöns, 2011; Nielsen, 2016; Uhly et al., 2017; Vabø et al., 2014). Research shows that female students and early-career researchers tend to be equally as mobile as men, but at advanced career stages (after 35 years of age), possibilities for women to relocate internationally become more difficult than for men (Jöns, 2011). Women's lower access to international research networks and weak support structures hinder mobility (Leemann, 2010; Uhly et al., 2017). In addition, gendered caregiving responsibilities and (immobile) partners have been identified as barriers to women's mobility (Ackers, 2008; Ackers \& Gill, 2008; Leemann, 2010; Vabø et al., 2014; Zippel, 2011). Nielsen (2017) showed that mobility requirements for tenured positions in a Danish university influenced women's considerations of leaving academia.

Just as gender segregation in academia reflects the stereotypical social division of labor between the sexes, with far more men in top positions and in STEM fields, it also reflects ethnic segregation along the gender dimension (Orupabo, 2016). Thus, women in academia do not compose a homogeneous group. Instead, there continue to be significant differences in possibilities for women from different ethnic backgrounds to be mobile and to pursue an international academic career (Mählck, 2013; Morley et al., 2018; Vabø et al., 2014).

\subsection{Scientific Fields and Global Academic Labor Markets}

The number and proportion of both women and foreignborn academics vary significantly by scientific field, which makes it crucial to pay attention to differences between fields when studying developments in staff composition. Although international mobility is increasingly seen as a requisite to progress in academic careers 
(Zippel, 2011), the expectation to be mobile continues to differ between scientific fields. International collaboration and mobility are especially important for academic careers in STEM, particularly at an early career stage (Herschberg et al., 2018; Zippel, 2011). In the social sciences and humanities, international research collaboration does not necessarily require physical mobility (Hakala, 2002), and recruitment criteria might be more detached from university internationalization policies (Herschberg et al., 2018). The differences are related not only to the different traditions of international collaboration but also to the use of languages in different fields and disciplines (Hakala, 1998; Jöns, 2007). STEM fields have traditionally been dominated by the use of the English language, whereas the languages of publications are more varied in the social sciences and humanities (Hakala, 1998).

Academic mobility is especially gendered in the natural sciences (Jöns, 2011). O'Hagan et al. (2019) showed how the need to seek professional visibility through international mobility in STEM has gendered consequences, as women are typically more restricted by family obligations.

Not only do STEM fields recruit high numbers of foreign-born academics, but these fields also display a higher research-to-teaching ratio compared with other fields, meaning that foreign-born researchers have low representation in the higher ranked, permanent positions (Smetherham et al., 2010). This indicates that there is a clearer division of work in these fields, with less opportunity for career progression. In the UK, the strong presence of non-UK academics in lower grade STEM positions could be due to a supply deficit, whereby local academics opt for a commercial career with better employment conditions than those available in academia (Ackers \& Gill, 2005; Khattab \& Fenton, 2016). The high proportion of foreign-born staff could also be due to high research funding in these fields, which allows universities to hire fixed-term staff and to continue to attract new talent, but not to develop candidates toward full professorships (Smetherham et al., 2010).

\section{Contextual Background}

Sweden, Norway, and Finland are comparatively small, open societies that engage in global research competition. Internationalization has become a strategic priority for Nordic governments and universities (Haapakoski \& Pashby, 2017; Stensaker et al., 2008). This includes the aim of attracting more researchers from abroad (Finnish Ministry of Education and Culture, 2017; Research Council of Norway, 2020; Swedish Government, 2018).

Nordic countries rank high on measures that have been identified as pull factors for foreign researchers, such as wage levels and expenditures for national research and development (R\&D; see Lepori et al., 2015). Sweden, Norway, and Finland all represent open systems where access for international applicants is not con- strained by formal barriers, such as accreditation systems for foreign PhD degrees (Afonso, 2016; Musselin, 2005). Yet, Finland has a weaker tradition of recruiting and retaining academics from abroad (Hoffman, 2007). In terms of possibilities for stable positions available for doctoral graduates (Afonso, 2016), Sweden and Norway can be considered systems with high security, whereas Finland represents a country with lower security and with more fixed-term positions. Better career prospects and financial resources for R\&D in Sweden and Norway (OECD, 2020) can be expected to have led to a higher proportion of foreign-born academics in Sweden and Norway than in Finland.

Despite the traditions of gender equality work in the Nordic countries-described as "women friendly societies" (Hernes, 1987)-and gender equality work in the research sector (Lipinsky, 2013), women continue to face obstacles when trying to reach positions at higher academic career stages. In 2018, the proportion of women in grade A positions was ca. 31 percent for Norway and 28 percent for Sweden and Finland (in headcounts). Thus far, the gender equality policies in Swedish, Norwegian and Finnish higher education and research have been detached from the internationalization policies (for Norway see Vabø, 2020). Thus, internationalization policies have not addressed the gender outcomes of global academic labor markets and international academic recruitment. In Norway, they are addressed for the first time in the 2021-2027 strategy of the Research Council of Norway (2020).

\section{Data and Method}

In this study, we use full-scale statistical data on TR staff employed at Swedish, Norwegian, and Finnish universities between 2012 and 2018.

The Swedish data, provided by Statistics Sweden, are a combination of several registers, where data on country origin come from the Multi-Generation Register. The data set has some missing information on the origin of staff (e.g., 4.2 percent of staff in grade $A$ and 1.4 percent of staff in grade C in 2018; see Supplementary File 1). We removed these data from the graphs. The Norwegian data come from NIFU's Register of Research Personnel and matched employer-employee register data from Statistics Norway. The Finnish data, provided by Statistics Finland, are a combination of higher education data on university staff and statistics on the population structure. We use headcounts, not full-time equivalents, because we are primarily interested in the total composition of university staff.

The two main variables are gender and countryorigin. Gender is a binary variable that differentiates between men and women. Country-origin is also a binary variable that differentiates between native-born and foreign-born staff. One advantage of country-origin is that it is unambiguous and constant (cf. citizenship, which might change), but it has some limitations. 
Most importantly, we do not know the reasons for, or timing of, mobility. However, the number of 'homegrown' TR staff with an immigrant background can be expected to be small (for Norway see Gunnes \& Steine, 2020; for Sweden see Swedish Higher Education Authority, 2019). In Norway, 80 percent of foreignborn researchers are international mobile researchers (Gunnes \& Steine, 2020). In Finland, the majority of foreign-born staff is also likely to be international mobile academics, given the small share of the immigrant population (seven percent in 2019; cf. 20 and 14 percent in Sweden and Norway, respectively; see Statistics Finland, 2019; Statistics Norway, 2019; Statistics Sweden, 2020). The vast majority of native-born staff in the three countries have two native-born parents. The proportion of second-generation immigrants among the TR staff of universities is low (our data; see also Gunnes \& Steine, 2020; Swedish Higher Education Authority, 2019). Another limitation of the data is that the data do not incorporate information on the countries of origin.

The data classify the TR staff of universities according to scientific field (all countries) and position (Sweden and Norway) or academic career stage (Finland). The classification of fields of science follows the OECD international classification system. The STEM fields include (natural) science, technology, engineering and mathematics. We merged agricultural sciences with natural sciences because of the low number of staff in agricultural sciences.

We use data on staff in grade $C$ and grade $A$ positions. Positions at these levels have strategic importance in the universities, and they are the most comparable across the three national systems. For example, grade $B$ positions include a more heterogeneous set of TR positions (e.g., university lecturers and senior researchers). Grade $C$ and $A$ positions are also more likely to be inclined to internationalization pressures than positions in grade $\mathrm{B}$, which are often closely related to teaching and thus to the use of national languages. In Sweden, grade $\mathrm{C}$ refers to career development positions, such as postdoctoral and assistant professor positions. In Norway, grade $\mathrm{C}$ entails postdoctoral positions. In Finland, grade $\mathrm{C}$ encompasses staff in career stage II, such as postdoctoral researchers. In Sweden and Norway, grade A positions refer to professor positions. In Finland, grade $A$ equals positions in career stage IV, the majority being professor positions. Hence, interpretations of the results should consider that the professional categories are not identical in the countries, which have somewhat different occupational structures and career logics, including different funding arrangements for R\&D. For example, the absolute number of persons in grade $C$ varies considerably between the countries, with the most people in Finland and the fewest in Norway (see Supplementary File 1).

In the analysis, we first calculated the proportion of foreign-born women, native-born women, foreign-born men, native-born men, all women and all foreign-born staff between 2012 and 2018 in grades C and A. We analyzed the overall national developments over time and compared the findings across the countries. Second, we examined the changes in the staff composition by scientific field in 2012 and 2018. Here, we focused on two fields that in 2012 had the lowest proportion of women in grades $C$ and $A$ : natural sciences and engineering and technology. These STEM fields have received significant policy attention due to the skewed gender distribution. For the comparability of the findings, we used proportions rather than headcounts in the analysis. Headcounts and data on (1) all fields and (2) STEM fields in grade C and $A$ are presented in tables in the Supplementary Files.

\section{Findings}

\subsection{Foreign-Born Staff and Women in Grade $C$ and $A$ Positions}

We first investigated how the composition of TR staff in grade C changed between 2012 and 2018, especially regarding the proportion of foreign-born staff and women. In all countries, the number of people in grade $C$ increased. The total headcounts and proportions can be found in Supplementary File 1.

Figure 1 shows that in all three countries, the proportion of foreign-born staff increased significantly, whereas correspondingly, the proportion of native-born staff decreased, especially that of native-born men. In Finland, the starting point differs, with a significantly lower proportion of foreign-born TR staff in 2012 (25 percent vs. 44 percent in Sweden and 50 percent in Norway). Sweden displays the strongest growth: The proportion of foreign-born staff increased by 24 percentage points and reached 68 percent in 2018. In Norway, the increase was 18 percentage points, which also led to 68 percent of foreign-born TR staff by 2018. In Finland, the increase was 12 percentage points, which led to 37 percent foreign-born staff. In all countries, the growth in foreign-born staff is due to a combination of an increase in the number of positions and a decline in absolute numbers of native staff.

When we look at gender differences, we see similar growth rates for foreign-born women and men in Finland (51 percent for both), whereas in Sweden, the increase was steeper among foreign-born women (61 percent; 49 percent for men) and in Norway, it was steeper for foreign-born men (38 percent; 34 percent for women). The proportion of all women remained quite steady in Sweden and Finland, at around 45 percent, whereas in Norway, it decreased from 48 percent to 46 percent.

Figure 2 shows the development of grade A. In Sweden and Norway, the number of people in grade $A$ increased, whereas in Finland, it decreased by 20 percent. As in grade $\mathrm{C}$, the starting points of the three countries differ considerably, with Finland having a lower proportion of foreign-born staff (8 percent in 2012; 10 percent in 2018) than Sweden (21 percent in 2012; 
Grade C positions

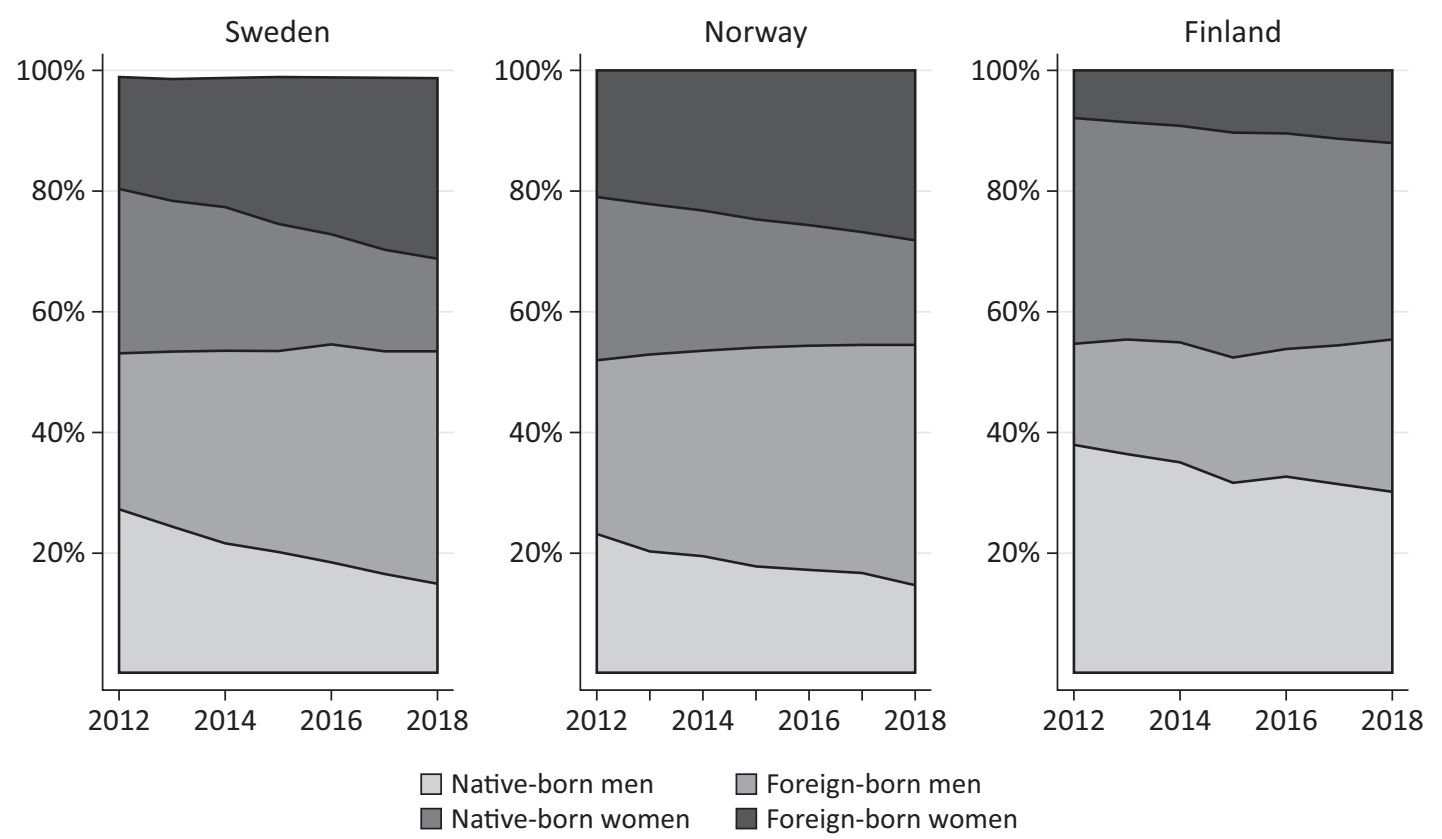

Figure 1. Staff in grade C at Swedish, Norwegian, and Finnish universities between 2012 and 2018 (percentage of all people in grade $\mathrm{C}$ ).

24 percent in 2018) and Norway (24 percent in 2012; 30 percent in 2018). Although the proportion of foreignborn staff increased, the changes were slower when compared with grade $C$. The stability is at least partly related to the nature of the positions: Grade A positions in the three countries are predominantly permanent, whereas grade $C$ positions typically last two to three years. There is a large discrepancy in gender bal- ance when we compare the proportion of women in grade $A$ and grade $C$ positions: The large share of women in grade $C$ is not reflected at the highest hierarchical level. However, an interesting and discernible trend in all the countries is the decline of native-born men, which indicates increased diversity in grade A. Female representation has improved in all three countries, with the strongest growth in Norway.

\section{Grade A positions}
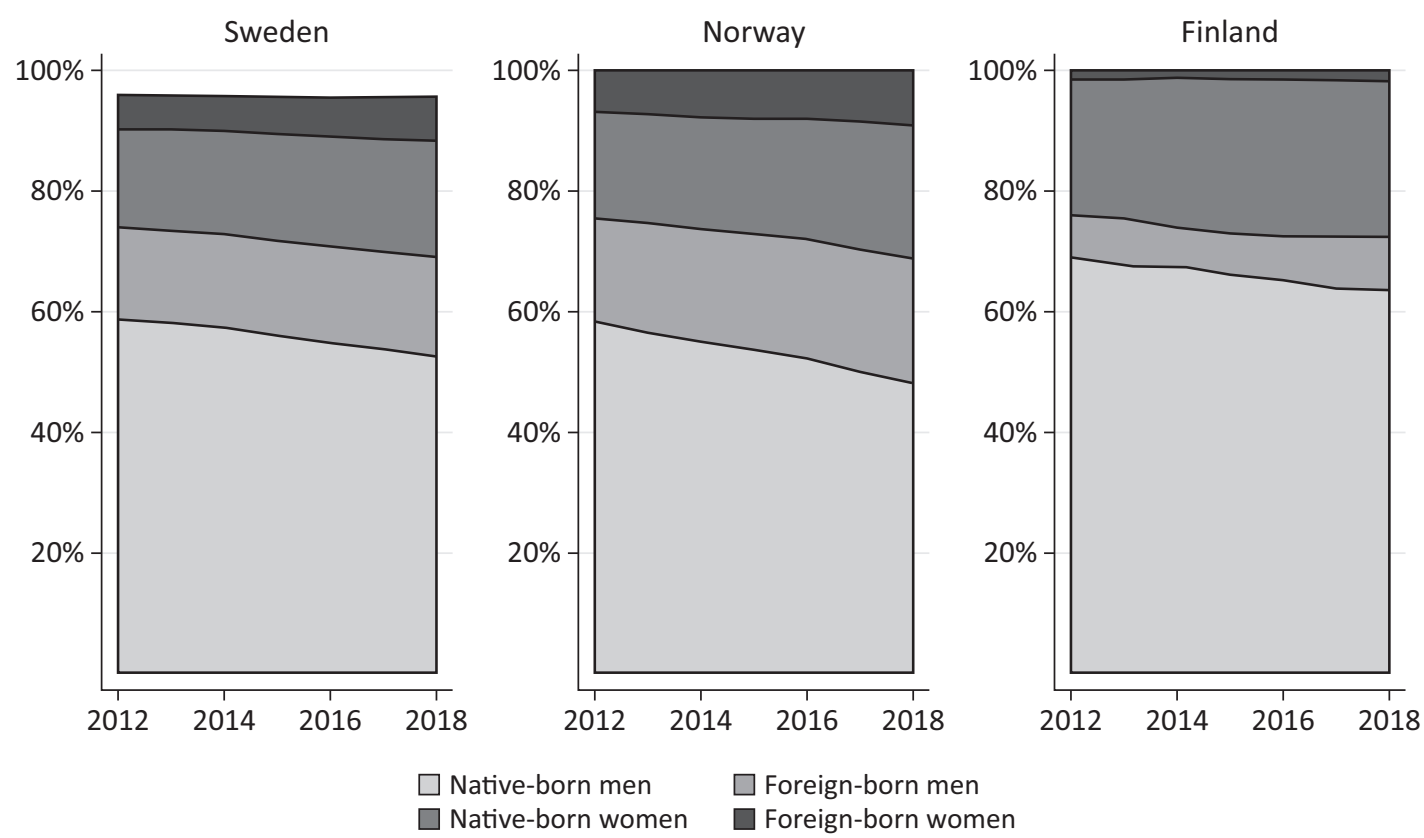

Figure 2. Staff in grade A at Swedish, Norwegian and Finnish universities between 2012 and 2018 (percentage of all people in grade $\mathrm{A})$. 
In Sweden, the drop among native-born men is compensated by an increase among native-born women ( 3 percentage points), foreign-born women ( 2 percentage points) and foreign-born men (1 percentage point). In Norway, the proportion of native-born women and foreign-born men increased by four percentage points, and foreign-born women by two percentage points. In Finland, the number of women in grade A positions went up and down, but in relative numbers, their proportion increased. The drop in the proportion of native men has been compensated by an increase among native women (three percentage points) and foreign-born men (two percentage points), whereas among foreign-born women, there was hardly any growth. In 2018, they constituted only 1.5 percent of staff in grade A.

\subsection{Foreign-Born Staff and Women in STEM}

We then move on to determine the composition of staff in grade $C$ and $A$ in STEM fields. The majority of staff in grade $C$ are postdoctoral researchers. Postdoc has long been a necessary career stage in STEM (Bessudnov et al., 2015).

Figure 3 shows that in Sweden, the proportion of foreign-born staff in grade $\mathrm{C}$ increased significantly, by 24 percentage points in the natural sciences (in 2018, the proportion was 76 percent) and 21 percentage points in engineering and technology (in 2018, the proportion was

Sweden

Grade C

Grade A
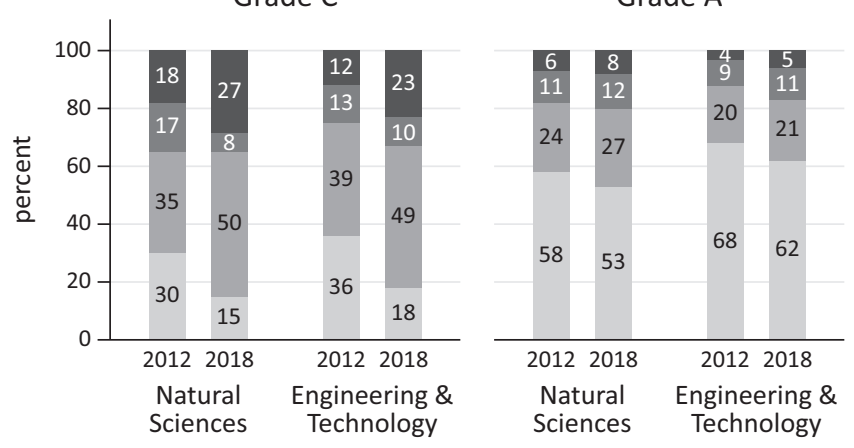

Norway

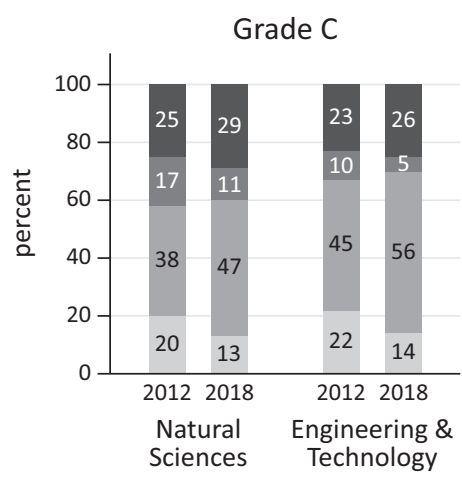

71 percent). The proportion of women remained stable at c. 35 percent in natural sciences and increased in engineering and technology from 25 percent to 33 percent. This increase among women is mostly due to the increase in the number and proportion of foreign-born women, who in 2018 clearly outnumbered native women.

Also in Norway, where the proportion of foreignborn staff was already high in 2012, the proportion increased by 13 percentage points in natural sciences (in 2018, their proportion was 76 percent, as in Sweden) and 14 percentage points in engineering and technology (reaching 82 percent in 2018). At the same time, the proportion of women decreased by a few percentage points, resulting in 39 percent in natural sciences and 31 percent in engineering and technology. This is explained especially by the increase among foreign-born men. Foreignborn women outnumbered native women, especially in technology and engineering.

When compared with Sweden and Norway, in Finland, the proportion of foreign-born staff was low in 2012: 31 percent in natural sciences and 28 percent in technology and engineering. Their proportion increased by 14 percentage points in natural sciences and by 20 percentage points in engineering and technology. Foreign-born staff were more skewed toward men than in Sweden and Norway. The proportion of women decreased by one percentage point in natural sciences (35 percent women in 2018) and increased

Figure 3. Staff in grades C and A in natural sciences and engineering and technology in 2012 and 2018 at Swedish, Norwegian and Finnish universities (percentage of all people in the scientific field). 
by two percentage points in engineering and technology (28 percent women in 2018). Although the number of foreign-born women increased and the number of native women decreased, native women still outnumbered foreign-born women in 2018.

Figure 3 shows that the increase among foreign-born staff in grade $C$ is not (at least yet) reflected in grade $A$. Furthermore, gender balance is more skewed toward men than in grade $\mathrm{C}$. Although the proportion of native men has decreased in all the countries, they still dominate grade $A$ positions in STEM, especially in Finland.

In Sweden, whereas native men comprised only 15-18 percent of grade C staff in STEM in 2018, in grade $A$, they represented the majority. However, the staff have become more diverse, as both the proportion of foreign-born staff and women has increased. The proportion of women increased by approximately 3-4 percentage points, quite similarly for native and foreignborn women, and reached 19 percent in natural sciences and 16 percent in engineering and technology.

In Norway, the proportion of foreign-born staff increased significantly in grade A: from 28 percent to 35 percent in the natural sciences, and from 27 percent to 39 percent in engineering and technology, the majority of them being men. The ratio of foreign-born to nativeborn staff is quite similar across both genders in grade $A$. Hence, we do not see the same intersecting gender and country-origin profiles that applied to grade $C$ positions in STEM. The proportion of women increased by approximately three percentage points, resulting in 20 percent in the natural sciences and 14 percent in engineering and technology, again quite similarly for native women and foreign-born women.

In Finland, as in grade $C$, the proportion of foreignborn staff was significantly lower in grade $A$ than in Sweden and Norway. In the time-frame, the overall number of people in grade A in STEM decreased. The proportion of foreign-born staff in grade $A$ increased also in Finland: from nine percent to 14 percent in natural sciences and from 12 percent to 17 percent in technology and engineering. It is notable that at both time points, nearly all foreign-born staff were men: Foreign-born women comprised less than one percent of grade A positions in STEM, and their low proportion even decreased in the 2010s. Overall, the proportion of women remained at a lower level than in Sweden and Norway and with small changes over the years: at approximately 16 percent in natural sciences, and with an increase from nine percent to 11 percent in engineering and technology.

\section{Discussion}

Today, international academic recruitment is an important part of building excellent research and teaching environments. Recruitment patterns in the Nordic region are an expression of a growing global labor market for academics. The global market for postdoctoral researchers in particular acts as a catalyst for a new recruitment prac- tice where international mobility is not only an ingredient for success in a scientific career but also contributes to legitimization of more deregulated and flexible working conditions, as expressed in the use of temporary positions (Vabø, 2020).

The findings indicate that the proportion of foreignborn staff increased rapidly in the 2010s, especially at Norwegian and Swedish universities. Interestingly, the gender distribution in grade $C$ has remained quite stable, with foreign-born men and women substituting nativeborn men and women. In grade A, native-born men have given way for women and foreign-born men. Compared with grade $\mathrm{C}$, the changes in the composition of TR staff in grade $A$ are modest, and native-born men maintain the majority share in all three countries.

There are several explanations for the differences in the increase of foreign-born staff between grade $C$ and grade $A$ positions. First, grade $A$ and grade $C$ are affected by different labor market dynamics. For example, there is likely to be a larger pool of applicants in grade $\mathrm{C}$ as international experience has become a qualification criterion among early career researchers (Vab $\varnothing$, 2020). Second, the pace of renewal differs between fixedterm grade $C$ positions and mostly permanent $A$ positions. Third, according to the Swedish Higher Education Authority (2020) increased international recruitment in grade $C$ is a result of specialization in STEM, which requires universities to enlarge their pool of applicants. Fourth, as in the UK (Khattab \& Fenton, 2016), potential native applicants for grade $C$ positions in the Nordic countries might find more attractive job opportunities outside the universities. For example, Frølich et al. (2019) argued that native Norwegians in STEM might find an attractive labor market outside universities, which might partly explain the large proportion of foreign-born staff in the temporary grade $\mathrm{C}$ positions.

In the Nordic comparison, Finland represents an outlier with a lower proportion of foreign-born staff, very few foreign-born women in grade $A$ and steeper gender segregation in STEM. Possible explanations for the lower level of foreign-born staff in Finland include shorter traditions of internationalization, openness of the society and the labor market toward foreigners, inbred recruitment, and governmental funding cuts in R\&D (Hoffman, 2007; OECD, 2020; Pietilä, 2015). What explains the low proportion of foreign-born women in grade $A$ requires further studies.

The contributions of this study derive from the combination of excellent empirical data and a novel analytical approach. First, we use register data that comprises all universities' TR staff in Sweden, Norway and Finland for almost a decade. This allows us to track changes within and between countries. To our knowledge, this is the first comparative study that addresses the intersecting patterns of gender and foreign origin among university staff in the Nordic context. Furthermore, the study illustrates the intensity of the globalization of academic labor markets also outside the English-speaking world, 
but with significant variation across national contexts. Moreover, the study contributes to existing research as it shows the varying gender outcomes of the changing academic labor market in the Nordic countries. For example, Swedish universities have been successful in attracting foreign-born women to engineering and technology in grade $\mathrm{C}$. As a result, the overall proportion of women has increased. In Norway, on the other hand, the proportion of women in STEM has slightly decreased, as the upsurge of foreign-born men has been so significant. Finally, this study contributes to research on social stratification in Nordic academia. The contrast between the diversity in grade $\mathrm{C}$ and the native- and male-dominated grade $\mathrm{A}$ is striking, and in line with the stratification found in the UK (Khattab \& Fenton, 2016; Smetherham et al., 2010). Thus, global recruitment acts as a catalyst for stronger stratification within the academic profession also in the Nordic countries.

In future studies, researchers should look more closely at the intersections of gender, country of origin, scientific field and position among foreign-born TR staff, as this would make it possible to discern differences in the universities' inclusionary practices and to analyze what barriers individuals with different backgrounds and genders encounter across their careers. Mählck (2013), for example, points to the different starting points and prejudices faced by women from different ethnic and cultural backgrounds entering Nordic academia. Our data cannot reveal the reasons behind the conspicuous socialdemographic differences in the composition of grade $A$ and grade $C$. Further studies should therefore focus on the mechanisms that lead to different staff compositions in specific national, organizational and disciplinary contexts.

The policy implication of our findings is that it is critical that policymakers in Nordic higher education and research include a clear intersectional dimension in their internationalization policies to acknowledge questions of country-origin and gender. The empirical data show that foreign-born women increasingly replace native women in grade $\mathrm{C}$, especially in Sweden and Norway. If the universities are not able or willing to keep mobile foreign-born women, a crucial question is whether universities will be able to maintain and increase the female share in grade A positions. Another pressing issue is that policymakers, as well as collegial bodies in Nordic universities and research systems, need to assess the effects of internationalization policies on the gender balance and social stratification of staff systematically. Universities should critically assess their recruitment processes to identify biases and procedures that may have discriminatory outcomes according to applicants' gender, ethnicity, and country-origin.

\section{Acknowledgments}

This work is part of the Nordic Centre for Research on Gender Equality in Research and Innovation (NORDICORE). NORDICORE is supported by the
NordForsk's Centre of Excellence funding, program "Gender in the Nordic Research and Innovation Area" (grant number 80713). We wish to thank Helena Wintgren at Statistics Sweden, Hebe Gunnes at NIFU, and Meri Juuti at Statistics Finland for help with the compilation of the statistical data.

\section{Conflict of Interests}

The authors declare no conflict of interests.

\section{Supplementary Material}

Supplementary material for this article is available online in the format provided by the author (unedited).

\section{References}

Ackers, L., \& Gill, B. (2005). Attracting and retaining 'early career' researchers in English higher education institutions. Innovation, 18(3), 277-299.

Ackers, L. (2008). Internationalisation, mobility and metrics: A new form of indirect discrimination? Minerva, 46, 411-435.

Ackers, L., \& Gill, B. (2008). Moving people and knowledge-Scientific mobility in an enlarging European Union. Edward Elgar.

Afonso, A. (2016). Varieties of academic labor markets in Europe. PS: Political Science \& Politics, 49(4), 816-821.

Askvik, T., \& Drange, I. (2019). Etnisk mangfold i akademia [Ethnic diversity in academia]. Søkelys på arbeidslivet, 36(3), 194-210.

Bauder, H. (2015). The international mobility of academics: A labour market perspective. International Migration, 53(1), 83-96.

Bessudnov, A., Guardiancich, I., \& Marimon, R. (2015). A statistical evaluation of the effects of a structured postdoctoral programme. Studies in Higher Education, 40(9), 1588-1604.

Crenshaw, K. (1989). Demarginalizing the intersection of race and sex: A black feminist critique of antidiscrimination doctrine, feminist theory, and antiracist politics. University of Chicago Legal Forum, 1989(1), 139-167.

Enders, J., \& Musselin, C. (2008). Back to the future? The academic profession in the 21st century. In OECD (Eds.), Higher education to 2030-Volume 1: Demography (pp. 125-150). OECD.

ETER Project. (2019). Internationalisation of academic staff in European higher education. European Tertiary Education Register.

European Commission. (2019). SHE figures 2018. European Commission, Directorate-General for Research and Innovation.

Finnish Ministry of Education and Culture. (2017). Suomalaisen korkeakoulutuksen ja tutkimuksen kansainvälisyyden edistämisen linjaukset 2017-2025, 
toimeenpano-ohjelma [Policy on the promotion of internationalization of Finnish higher education and research 2017-2025, implementation plan].

Fontes, M., Videira, P., \& Calapez, T. (2013). The impact of long-term scientific mobility on the creation of persistent knowledge networks. Mobilities, 8(3), 440-465.

Frølich, N., Reiling, R. B., Gunnes, H., Mangset, M., Orupabo, J., Ulvestad, M. E. S., Østbakken, K. M. Lyby, L., \& Larsen, E. H. (2019). Attraktive akademiske karrierer? Søkning, rekruttering og mobilitet $i$ UH-sektoren. [Attractive academic careers? Applications, recruitment and mobility in the university sector] (Report 2019-10). NIFU.

Gornitzka, A., \& Langfeldt, L. (Eds.). (2009). Borderless knowledge: Understanding the "new" internationalisation of research and higher education in Norway. Springer.

Gunnes, H., \& Steine, F. S. (2020). Mangfoldsstatistikk. Stor vekst $i$ antall forskere med utenlandsk bakgrunn [Diversity statistics. Large growth in the number of foreign researchers] (Report No. 17). NIFU.

Haapakoski, J., \& Pashby, K. (2017). Implications for equity and diversity of increasing international student numbers in European universities: Policies and practice in four national contexts. Policy Futures in Education, 15(3), 360-379.

Hakala, J. (1998). Internationalisation of science. Views of the scientific elite in Finland. Science Studies, 11(1), 52-74.

Hakala, J. (2002). Internationalisation of researchNecessity, duty or waste of time? Academic cultures and profiles of internationalization. VEST: Journal for Science and Technology Studies, 15(1), 7-32.

Hernes, H. (1987). Welfare state and woman power: Essays in state feminism. Oxford University Press.

Herschberg, C., Benschop, Y., \& van den Brink, M. (2018). Selecting early-career researchers: The influence of discourses of internationalisation and excellence on formal and applied selection criteria in academia. Higher Education, 76(5), 807-825.

Hoffman, D. M. (2007). The career potential of migrant scholars: A multiple case study of long-term academic mobility in Finnish universities. Higher Education in Europe, 32(4), 317-331.

Horta, H., Veloso, F. M., \& Grediaga, R. (2010). Navel gazing: Academic inbreeding and scientific productivity. Management Science, 56(3), 414-429.

Huang, F., Rostan, M., \& Finkelstein, M. (Eds.). (2014). The internationalization of the academy: Changes, realities and prospects. Springer.

Jonkers, K., \& Tijssen, R. (2008). Chinese researchers returning home: Impacts of international mobility on research collaboration and scientific productivity. Scientometrics, 77, 309-333.

Jöns, H. (2007). Transnational mobility and the spaces of knowledge production. A comparison of global patterns, motivations and collaborations in different aca- demic fields. Social Geography, 2, 97-114.

Jöns, H. (2011). Transnational academic mobility and gender. Globalisation, Societies and Education, 9(2), 183-209.

Khattab, N., \& Fenton, S. (2016). Globalisation of researcher mobility within the UK higher education: Explaining the presence of overseas academics in the UK academia. Globalisation, Societies and Education, 14(4), 528-542.

Leemann, R. J. (2010). Gender inequalities in transnational academic mobility and the ideal type of academic entrepreneur. Discourse: Studies in the Cultural Politics of Education, 31(5), 605-625.

Lepori, B., Seeber, M., \& Bonaccorsi, A. (2015). Competition for talent. Country and organizationallevel effects in the internationalization of European higher education institutions. Research Policy, 44(3), 789-802.

Lipinsky, A. (2013). Gender equality policies in public research: Based on a survey among members of the Helsinki group on gender in research and innovation. European Commission. https://op.europa.eu/en/ publication-detail/-/publication/39136151-cb1f417c-89fb-a9a5f3b95e87

Mählck, P. (2013). Academic women with migrant background in the global knowledge economy: Bodies, hierarchies and resistance. Women's Studies International Forum, 36, 655-674.

Metcalfe, B. D., \& Woodhams, C. (2012). Introduction: New directions in gender, diversity and organization theorizing: Re-imagining feminist post-colonialism, transnationalism and geographies of power. International Journal of Management Reviews, 14(2), 123-140.

Morley, L., Alexiadou, N., Garaz, S., GonzálezMonteagudo, J., \& Taba, M. (2018). Internationalisation and migrant academics: The hidden narratives of mobility. Higher Education, 76(3), 537-554.

Musselin, C. (2004). Towards a European academic labour market? Some lessons drawn from empirical studies on academic mobility. Higher Education, 48(1), 55-78.

Musselin, C. (2005). European academic labor markets in transition. Higher Education, 49, 135-154.

Nielsen, M. W. (2016). Gender inequality and research performance: Moving beyond individualmeritocratic explanations of academic advancement. Studies in Higher Education, 41(11), 2044-2060.

Nielsen, M. W. (2017). Reasons for leaving the academy: A case study on the 'opt out' phenomenon among younger female researchers. Gender, Work \& Organization, 24(2), 134-155.

Norbal database. (2021). NORBAL-Doctoral degrees in the Nordic and Baltic countries. NIFU.

O'Hagan, C., O'Connor, P., Myers, E. S., Baisner, L., Apostolov, G., Topuzova, I., Saglamer, G., Tan, M., \& Çağlayan, H. (2019). Perpetuating academic capital- 
ism and maintaining gender orders through career practices in STEM in universities. Critical Studies in Education, 60(2), 205-225.

Organisation for Economic Co-operation and Development. (2020). Main science and technology indicators 2020.

Orupabo, J. (2016). Kvinnejobber, mannsjobber og innvandrerjobber [Women's jobs, men's jobs and immigrants' jobs]. Cappelen Damm akademisk.

Pietilä, M. (2015). Tenure track career system as a strategic instrument for academic leaders. European Journal of Higher Education, 5(4), 371-387.

Research Council of Norway. (2020). Action plan for internationalisation 2021-2027. The Research Council of Norway.

Smetherham, C., Fenton, S., \& Modood, T. (2010). How global is the UK academic labour market? Globalisation, Societies and Education, 8(3), 411-428.

Statistics Finland. (2019). Immigrants in the population. Statistics Finland. www.stat.fi/tup/maahanmuutto/ maahanmuuttajat-vaestossa_en.html

Statistics Norway. (2019). Lavere vekst i antall innvandrere [Lower growth in the number of immigrants]. Statistics Norway.

Statistics Sweden. (2020). Statistikdatabasen [Statistical database]. www.scb.se/hitta-statistik/ statistik-efter-amne/utbildning-och-forskning/ hogskolevasende/personal-vid-universitet-ochhogskolor/\#_TabelleriStatistikdatabasen

Stensaker, B., Frølich, N., Gornitzka, Å., \& Maassen, P. (2008). Internationalisation of higher education: The gap between national policy-making and institutional needs. Globalisation, Societies and Education, 6(1), 1-11.

Swedish Government. (2018). En strategisk agenda för internationalisering [Strategic agenda for internationalisation]. Statens Offentliga Utredningar.
Swedish Higher Education Authority. (2019). Higher education institutions in Sweden-2019 Status report.

Swedish Higher Education Authority. (2020). Internationella rekryteringar vanligast bland yngre forskare [International recruitment most frequent among younger researchers] (Statistical analysis 2020-0421/217-20-1).

Teichler, U. (2015). Academic mobility and migration: What we know and what we do not know. European Review, 23(S1), S6-S37.

Uhly, K. M., Visser, L. M., \& Zippel, K. S. (2017). Gendered patterns in international research collaborations in academia. Studies in Higher Education, 42(4), 760-782.

Vabø, A. (2020). Relevansen av internasjonal rekruttering for arbeidsbetingelser i forskning og høyere utdanning. [The relevance of international recruitment for working conditions in higher education and research]. Norsk sosiologisk tidsskrift, 4(1), 34-41.

Vabø, A., \& Wiers-Jenssen, J. (2014). Internationalization, diversification and quality in higher education. Zeitschrift für Pädagogik, 60(5), 710-723.

Vabø, A., Padilla-González, L., Waagene, E., \& Næss, T. (2014). Gender and faculty internationalization. In F. Huang, M. Finkelstein, \& M. Rostan (Eds.), The internationalization of the academy: Changes, realities and prospects (pp. 183-205). Springer Science+Business Media.

van der Wende, M. (2015). International academic mobility: Towards a concentration of the minds in Europe. European Review, 23(S1), S70-S88.

Zippel, K. (2011). How gender neutral are state policies on science and international mobility of academics? Sociologica, 5(1), 1-18.

Zippel, K. (2017). Women in global science: Advancing academic careers through international collaboration. Stanford University Press.

\section{About the Authors}

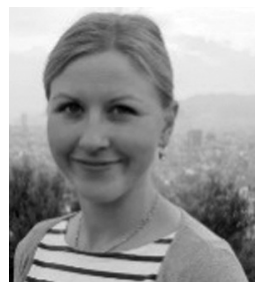

Maria Pietilä is Postdoctoral Researcher in Human Resources Services at the University of Eastern Finland. Her previous contract was in the field of political science at the University of Helsinki. She has done research on academic career systems and gender equality policies in higher education. Pietilä is part of the Nordic Centre for Research on Gender Equality in Research and Innovation (NORDICORE). She is currently involved in a Horizon 2020 project on the renewal of academic career structures based on open science criteria.

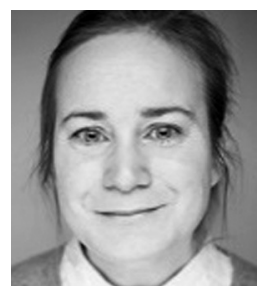

Ida Drange (PhD) is Research Professor at Oslo Metropolitan University in the field of labor market studies, with special emphasis on diversity issues and labor market integration of highly educated immigrants. Her research encompasses immigrant career outcomes in relation to employment, job mobility, wage developments and occupational accreditation for migrating professionals. She has also done research on workplace democracy, trade unions and work environment factors. Drange is part of NORDICORE. 


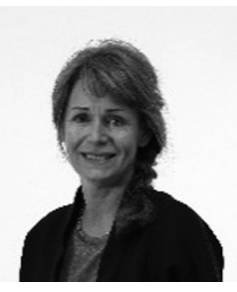

Charlotte Silander is Associate Professor in political science at the department of Didactics and Teachers practices, Linnaeus University, Sweden. Her research focuses on academic careers and diversity policy in higher education. Her research includes studies on gender equality policy and research policy of higher education. As a leader of the project "Gender Equality and Diversity Policies in Nordic Universities," part of NORDICORE, she has studied equality policies in the Nordic countries on national and institutional level.

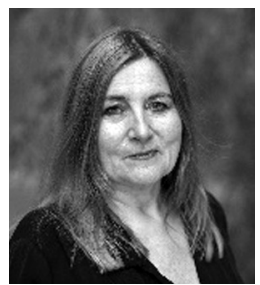

Agnete Vabø is Associate Professor at Oslo Metropolitan University where she teaches in public governance and administration. She holds a dr. polit degree in sociology. She holds an adjunct position as research professor at the Nordic Institute for Studies in Innovation, Science and Education, NIFU. Vab $\varnothing$ has published numerous research reports, books, and articles in higher education and science studies. She is PI of the project "Gender, Academic Power and Citizenship," funded by the Research Council of Norway. 